\title{
Konsumsi lemak total, lemak jenuh, dan kolesterol sebagai faktor risiko sindroma metabolik pada masyarakat perkotaan di Denpasar ${ }^{1}$
}

\author{
Ni Komang Wiardani ${ }^{2}$, Pande Putu Sri Sugiani ${ }^{2}$, Ni Made Yuni Gumala²
}

\begin{abstract}
Background: Metabolic syndrome is a health problem with its prevalence increasing in the worldwide. It is characterized by a group metabolic factor including abdominal obesity, dyslipidemia, elevated blood pressure and insulin resistance. Metabolic syndrome affected by changes in lifestyle and unhealthy dietary patterns with high cholesterol, saturated fatty acid and trans fatty acid.

Objective: The study conducted to know relationship between fat consumption with metabolic syndrome among adult people in Denpasar city.

Method: The case control study designed was applied. The cases were adult people who had metabolic syndrome, and the control was healthy people from the case-neighboring household. Total subject were 130, taken by consecutive sampling: 65 cases and 65 controls. The subject identity, fat intake, waist circumference, blood pressure and fasting blood sugar were collected. The food frequency questionnaire (FFQ) was used to measure fat consumption and blood glucose test meter for measuring fasting blood sugar. Mantel Haenzel statistic analysis were used to test the association of fat intake with metabolic syndrome.

Result: The study showed that means of syndrome metabolic component in case higher than control $(p<0.05)$. Waist circumference in case was $97.23 \mathrm{~cm}$, blood pressure was $141.4 / 93.3 \mathrm{mmHg}$, fasting blood glucose was $132 \mathrm{mg} / \mathrm{dl}$. There were significant difference between intake fat total, cholesterol, saturated fatty acid (SAFA) and frequency of intake in case and control $(p<0.05)$. Intake fat on cases were fat total $85.5 \%>25 \%$ energy total/day, SAFA $90.8 \%>10 \%$, cholesterol $55.4 \%>300 \mathrm{mg} /$ day. Odd Ratio Mantel Haenzel analysis showed that fat consumption (fat total, cholesterol and frequency consumption of fat were risk factor to metabolic syndrome $(O R>1))$.

Conclusion: There was significant relations between fat consumption (fat total cholesterol, SAFA, frequency of fat consumption) with metabolic syndrome among adult people for Denpasar City.
\end{abstract}

KEY WORDS fat consumption, metabolic syndrome

\section{PENDAHULUAN}

Adanya kemajuan di bidang teknologi memberikan dampak terhadap perubahan gaya hidup dan pola makan di masyarakat. Pada masa kini, pola konsumsi masyarakat sudah mengalami perubahan, tidak lagi mengonsumsi makanan seimbang yang terdiri dari beraneka ragam jenis makanan dengan kandungan zat gizi lengkap dan seimbang, tetapi cenderung mengonsumsi makanan yang mengandung tinggi lemak terutama lemak jenuh, kolesterol, dan rendah serat. Kondisi seperti ini banyak ditemukan pada masyarakat yang tinggal di daerah perkotaan termasuk kota Denpasar sebagai akibat perubahan gaya hidup yang sudah mengarah kepada gaya hidup modern. Penelitian di Denpasar menemukan telah terjadi pergeseran pola konsumsi energi masyarakat kota Denpasar dari sumber karbohidrat ke sumber lemak, karena masyarakat menitikberatkan protein hewani untuk memenuhi kebutuhan protein (1).

Terjadinya pergeseran pola makan di kota-kota besar dari pola makan tradisional ke pola makan Western, yang komposisinya terlalu tinggi lemak dan rendah serat, menimbulkan ketidakseimbangan asupan gizi dan merupakan faktor risiko yang sumbangannya sangat besar terhadap munculnya berbagai masalah kesehatan seperti obesitas, hipertensi, dislipidemia, dan resistensi insulin yang dikenal dengan sindroma metabolik (2). Hasil penelitian di Teheran menunjukkan terdapat hubungan antara pola konsumsi dengan kejadian sindroma metabolik pada penduduk perempuan dengan pola konsumsi tinggi karbohidrat, produk tinggi lemak, mentega, dan rendah sayuran yang berkaitan dengan bertambahnya risiko sindroma metabolik (3). ${ }^{1}$

Sindroma metabolik sebagai masalah kesehatan terus meningkat di negara maju dan negara berkembang termasuk Indonesia. Beberapa hasil penelitian empiris memperkirakan sindroma metabolik ditemukan sebanyak $22 \%$ pada orang yang mengalami overweight dan $60 \%$ pada orang yang obesitas. Hasil penelitian di Amerika Serikat menunjukkan prevalensi sindroma metabolik pada penduduk dewasa sekitar 21,8\% (4). Prevalensi sindroma metabolik meningkat dengan bertambahnya usia sekitar $10 \%$ pada penduduk usia 20 tahun dan mencapai $40 \%$ pada usia 60 tahun. Meskipun belum ada data yang jelas

\footnotetext{
1 Dipresentasikan pada ......

2 Jurusan Gizi Poltekkes Denpasar, Jalan Gemitir no 72 Denpasar (Telp 0361 465232)
} 
mengenai prevalensi sindroma metabolik di Indonesia, tetapi data riset kesehatan dasar (Riskesdas 2007) menunjukkan prevalensi komponen sindroma metabolik seperti obesitas sentral sekitar 18,8\%, hipertensi $29,8 \%$, dan diabetes mellitus pada penduduk perkotaan sekitar $5,7 \%$ (5). Penelitian yang dilakukan di Bali menunjukkan prevalensi sindroma metabolik pada laki-laki sebesar $11,28 \%$ dan pada perempuan $20,38 \%$ (6).

Peningkatan prevalensi sindroma metabolik memberikan dampak yang buruk terhadap kelangsungan hidup seseorang. Penelitian di berbagai tempat menunjukkan bahwa angka kesakitan dan kematian penyakit kardiovaskuler akibat sindroma metabolik meningkat secara bermakna (7). Penelitian di Amerika Serikat memperlihatkan bahwa $21,7 \%$ pasien gangguan jantung dengan sindroma metabolik mengalami kejadian kardiovaskuler dan kematian (8).

Penelitian di Poliklinik Geriatri RSUP Sanglah Denpasar, membuktikan bahwa konsumsi lemak tinggi akan berisiko 3,8 kali lebih besar terkena sindrom metabolik dibandingkan dengan konsumsi lemak yang rendah (OR=3,8; IK 95\%:1,1-13,2). Hasil uji multivariat menunjukkan konsumsi lemak tinggi pada kasus berisiko 4,9 kali lebih besar terjadinya sindrom metabolik ( $O R=4,9$; IK 95\%:1,17-20,61) (9). Hal ini diperkuat dengan hasil penelitian di Kalimantan pada karyawan di Perusahaan Unocal Oil Company Balikpapan yang menunjukkan bahwa ada hubungan yang signifikan antara konsumsi lemak yang melebihi angka kecukupan gizi (AKG) dengan kejadian sindroma metabolik $(O R=5,04)(10)$. Hal ini menunjukkan bahwa sindroma metabolik serta faktor risikonya perlu mendapatkan perhatian serius agar tidak mengarah pada berkembangnya penyakit degeneratif. Penelitian ini bertujuan untuk mengetahui hubungan pola konsumsi lemak dengan kejadian sindroma metabolik pada masyarakat perkotaan di Denpasar.

\section{BAHAN DAN METODE}

Penelitian ini merupakan penelitian analitik observational dengan rancangan case control study. Penelitian dimulai dengan mengidentifikasi individu yang mengalami sindroma metabolik (kasus) dan dicarikan kontrol yang sebanding tetapi tidak mengalami sindroma metabolik. Selanjutnya faktor risiko yang dianggap berperan (pola konsumsi lemak) ditelusuri secara retrospektif selama 3 bulan terakhir. Penelitian dilaksanakan di Kota Denpasar dengan waktu penelitian selama 3 bulan yaitu bulan Oktober sampai Desember 2009.

Populasi penelitian adalah penduduk usia dewasa pada masyarakat perkotaan di Denpasar. Subjek adalah sebagian dari populasi dengan kriteria inklusi yaitu laki-laki maupun perempuan dewasa berumur 20 tahun sampai 55 tahun, belum pernah didiagnosis penyakit sindroma metabolik, bertempat tinggal tetap di kota Denpasar, dan bersedia menjadi subjek penelitian. Subjek dibagi dua kelompok yaitu kasus (subjek yang mengalami sindroma metabolik) dan kontrol (individu sehat tidak mengalami sindroma metabolik) yang di "matching" terhadap umur dan jenis kelamin. Berdasarkan perhitungan besar sampel untuk studi kasus kontrol berpasangan (11), dengan nilai Odds Ratio (OR) sebesar 2, $\alpha=0,05$ dan $ß=0,2$ karena kekuatan uji yang diinginkan adalah $80 \%$, besar sampel diperoleh 65 orang untuk setiap kelompok dengan total subjek 130 orang, yang dikumpulkan dengan menggunakan metode consecutive sampling pada seluruh kecamatan di kota Denpasar.

Jenis data yang dikumpulkan meliputi identitas subjek dengan wawancara menggunakan formulir identitas subjek, pola konsumsi lemak (jenis lemak dan frekuensi konsumsi) menggunakan formulir food frequency questionaire (FFQ). Data kejadian sindroma metabolik meliputi 3 komponen yaitu pengukuran lingkar pinggang dengan pita lingkar pinggang elastis skala 0-150 cm, tekanan darah dengan tensimeter merk Citizen, dan kadar gula darah puasa menggunakan alat biosensor glukosa merk Nesco. Penelitian dilakukan oleh tim peneliti dibantu tenaga paramedis puskesmas dan enumerator yaitu mahasiswa DIII Jurusan Gizi Poltekkes Denpasar.

Data yang diperoleh kemudian diproses dengan program software komputer dan digunakan analisis statistik univariat, bivariat. Data identitas subjek dikompilasi dan disajikan dalam bentuk distribusi frekuensi, data pola konsumsi lemak meliputi jumlah lemak total, lemak jenuh, dan kolesterol dianalisis dengan program Nutri Survey kemudian dibandingkan dengan persentase konsumsi yang dianjurkan dan dikelompokkan menjadi 2 kategori yaitu lemak total baik: jika persentase energi lemak total kurang atau sama dengan $25 \%$ dan lemak total kurang baik: jika lebih dari $25 \%$. Lemak jenuh baik: jika kurang atau sama dengan $10 \%$ total energi per hari dan lemak kurang baik: jika lebih dari $10 \%$ total energi per hari, kolesterol baik: jika kurang atau sama dengan 300 mg per hari, kolesterol kurang baik: jika lebih dari 300 mg per hari. Frekuensi konsumsi sering jika frekuensi konsumsi sumber lemak lebih dari 1 kali seminggu, dan jarang jika kurang atau sama dengan 1 kali seminggu. Kategori sindroma metabolik menggunakan kriteria National Cholesterol Education Program Adult Treatment Panel (NCEP-ATP II) modifikasi, dengan minimal 3 komponen yaitu lingkar pinggang lebih atau sama dengan $90 \mathrm{~cm}$ pada laki-laki dan lebih atau sama dengan $80 \mathrm{~cm}$ pada perempuan, tekanan darah lebih dari 130/85 $\mathrm{mmHg}$, dan gula darah puasa kurang atau sama dengan $110 \mathrm{mg} /$ dl. Analisis Chi Square dilakukan untuk menilai perbedaan proporsi pola konsumsi lemak pada kasus dan kontrol. Analisis Odd Ratio (OR) Mantel Haenzel dilakukan untuk menilai hubungan atau besarnya faktor risiko pola konsumsi lemak dengan kejadian sindroma metabolik. 


\section{HASIL DAN BAHASAN}

\section{Karakteristik subjek}

Skrining dilakukan terhadap 200 penduduk dewasa di kota Denpasar untuk memperoleh subjek penelitian yang sesuai dengan kriteria yang ditetapkan. Jumlah subjek penelitian yang terlibat dalam penelitian sebanyak 130 orang yang terdiri dari kasus berjumlah 65 orang dan kontrol berjumlah 65 orang dengan perbandingan kasus dan kontrol 1:1 yang telah dilakukan matching terhadap umur dan jenis kelamin.

Berdasarkan hasil penelitian diperoleh data ratarata umur kasus 42,2 tahun $( \pm 7,4$ tahun) dengan umur terendah 21 tahun dan tertinggi 55 tahun. Rata-rata umur kontrol 41,43 tahun ( $\pm 7,2$ tahun) dengan umur terendah 22 tahun dan tertinggi 54 tahun. Sebagian besar kasus dan kontrol berada pada kelompok umur lebih dari 40 tahun. Data karakterisktik subjek disajikan pada Tabel 1.

Tabel 1. Distribusi kasus dan kontrol menurut karakteristik

\begin{tabular}{llcccr}
\hline \multirow{2}{*}{ Karakterisik } & \multicolumn{2}{c}{ Kasus } & \multicolumn{2}{c}{ Kontrol } \\
\cline { 3 - 6 } & & $\mathbf{n}$ & $\mathbf{\%}$ & $\mathbf{n}$ & \multicolumn{1}{c}{$\%$} \\
\hline Jenis & Laki-laki & 35 & 53,8 & 35 & 53,8 \\
kelamin & Perempuan & 30 & 46,2 & 30 & 46,2 \\
& Total & $\mathbf{6 5}$ & $\mathbf{1 0 0 , 0}$ & $\mathbf{6 5}$ & $\mathbf{1 0 0 , 0}$ \\
Kelompok & $<30$ tahun & 5 & 7,7 & 7 & 10,8 \\
umur & 30-40 tahun & 18 & 27,7 & 18 & 27,7 \\
& $>$ 40 tahun & 42 & 64,6 & 40 & 61,5 \\
Tingkat & Total & $\mathbf{6 5}$ & $\mathbf{1 0 0 , 0}$ & $\mathbf{6 5}$ & $\mathbf{1 0 0 , 0}$ \\
pendidikan & Tak Sekolah/SD & 6 & 9,2 & 2 & 3,1 \\
& SLTP & 9 & 13,8 & 4 & 6,2 \\
& SLTA & 21 & 32,3 & 34 & 52,3 \\
& PT & 29 & 44,7 & 25 & 38,4 \\
Pekerjaan & Total & $\mathbf{6 5}$ & $\mathbf{1 0 0 , 0}$ & $\mathbf{6 5}$ & $\mathbf{1 0 0 , 0}$ \\
& Tak Bekerja/IRT & 8 & 12,3 & 13 & 20,0 \\
& Pedagang & 8 & 12,3 & 3 & 4,6 \\
& PNS & 22 & 33,8 & 22 & 33,8 \\
& Karyawan swasta & 17 & 26,2 & 14 & 21,6 \\
& Wiraswasta & 10 & 15,4 & 13 & 20,0 \\
& Total & $\mathbf{6 5}$ & $\mathbf{1 0 0 , 0}$ & $\mathbf{6 5}$ & $\mathbf{1 0 0 , 0}$ \\
\hline
\end{tabular}

\section{Pola konsumsi lemak}

Persentase konsumsi lemak total. Proporsi lemak yang dianggap baik bagi seseorang untuk mempertahankan kesehatan yang optimal adalah $25 \%$ dari total energi sehari. Hasil penelitian menunjukkan terdapat perbedaan signifikan antara pola konsumsi lemak pada kasus dan kontrol $(p<0,05)$. Sebagian besar kasus yaitu 53 orang $(81,5 \%)$ memiliki konsumsi lemak tinggi $(\geq 25 \%$ total energi), sedangkan 12 orang (18,5\%) konsumsi lemak total lebih dari atau sama dengan $25 \%$ total energi. Persentase konsumsi lemak kontrol 41 orang $(63,1 \%)$ dengan kategori kurang baik dapat dilihat di Gambar 1.

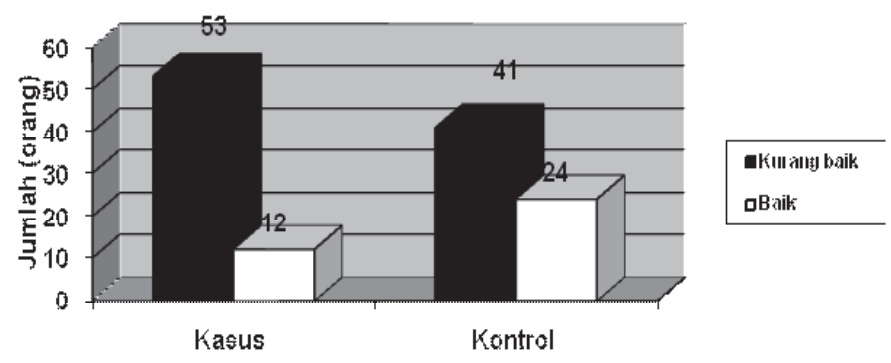

Gambar 1. Distribusi kasus dan kontrol berdasarkan persentase lemak total

Persentase konsumsi lemak jenuh. Konsumsi lemak jenuh yang baik maksimal $10 \%$ dari total energi yang dikonsumsi sehari. Hasil penelitian menunjukkan bahwa baik kasus atau kontrol sebagian besar mengonsumsi lemak jenuh dengan kategori kurang baik $(>10 \%)$ dari total energi yang dikonsumsi walaupun proporsi pada kasus lebih besar yaitu 59 orang $(90,8 \%)$ sedangkan 49 orang $(75,4 \%)$ pada kontrol dan perbedaan tersebut signifikan $(p<0,05)$. Distribusi konsumsi lemak jenuh pada kasus dan kontrol dapat dilihat pada Gambar 2.

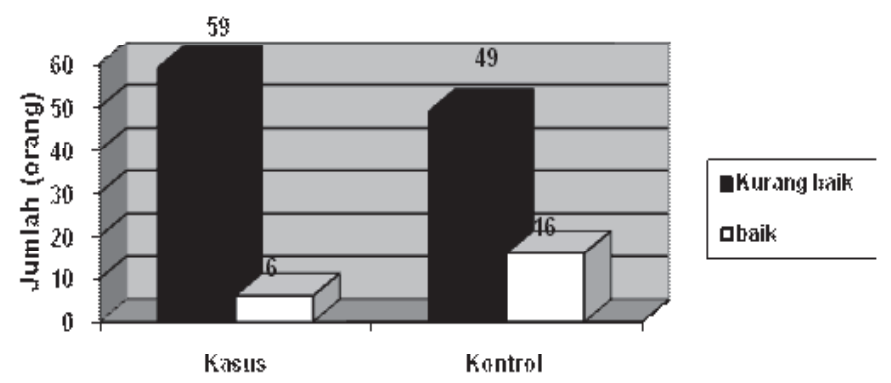

Gambar 2. Proporsi konsumsi lemak jenuh pada kasus dan kontrol

Konsumsi kolesterol. Jumlah kolesterol yang dianjurkan untuk dikonsumsi adalah kurang dari atau sama dengan $300 \mathrm{mg}$ per hari. Sebanyak 36 kasus $(55,4 \%)$ mengonsumsi kolesterol dengan kategori baik dan 29 kasus mengonsumsi kolesterol dengan kategori kurang baik, sedangkan sebagian besar kontrol sebanyak 45 orang $(69,2 \%)$ mengonsumsi kolesterol dengan kategori baik (kurang dari atau sama dengan $300 \mathrm{mg}$ per hari).

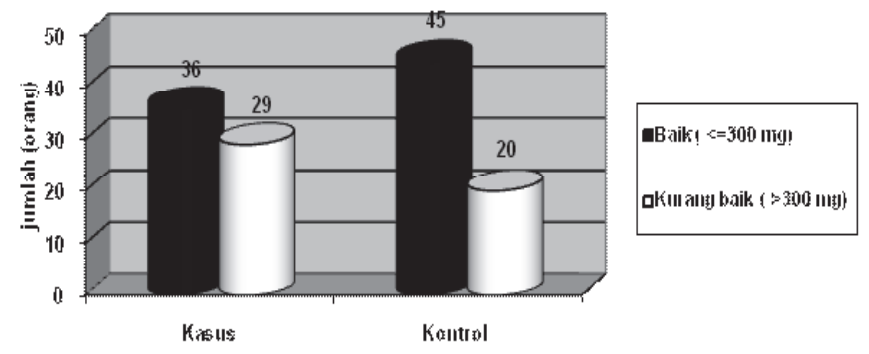

Gambar 3. Distribusi kasus dan kontrol berdasarkan konsumsi kolesterol 
Frekuensi konsumsi sumber lemak. Sumber lemak yang dikonsumsi adalah bahan makanan sumber hewani serta hasil olahannya seperti minyak kelapa, mentega, dan margarin. Sumber hewani yang dikonsumsi merupakan sumber lemak jenuh dan kolesterol berasal dari daging ayam, daging babi, daging kambing, daging sapi, jeroan, dan lain-lain. Sedangkan sumber lemak tak jenuh yang dikonsumsi sebagian besar bersumber dari ikan dan lemak nabati seperti kacang-kacangan dan minyak sayuran. Sumber lemak hewani yang biasa dikonsumsi di antaranya adalah daging ayam, daging sapi, dan daging babi, sedangkan sumber lemak tak jenuh yang biasa dikonsumsi adalah ikan laut.

Hasil penelitian menunjukkan proporsi kasus yang mengonsumsi sumber lemak jenuh dan kolesterol dengan frekuensi sering lebih besar dibandingkan kontrol yaitu kasus 56 orang $(86,2 \%)$ sedangkan kontrol 41 orang $(63,2 \%)$.

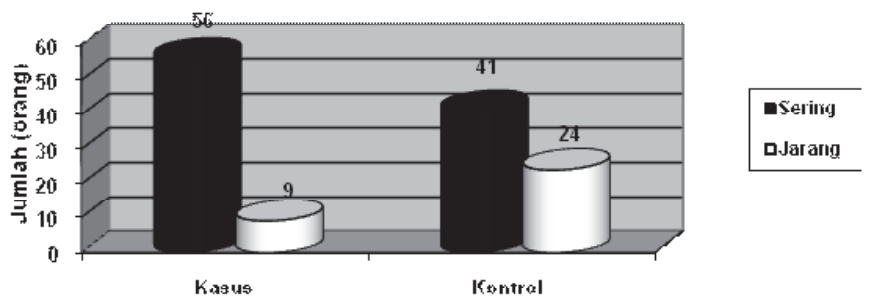

Gambar 4. Distribusi kasus dan kontrol berdasarkan frekuensi konsumsi sumber lemak jenuh

Frekuensi konsumsi sumber lemak tak jenuh. Konsumsi lemak tak jenuh pada kasus dan kontrol lebih banyak bersumber dari ikan dan kacang kacangan. Hasil penelitian menunjukkan tak ada perbedaan konsumsi lemak tak jenuh pada kasus dan kontrol $(p>0,05)$. Kasus dan kontrol sebagian besar mengkonsumsi sumber lemak tak jenuh dengan frekuensi sering (>1 x/minggu) (Gambar 5).

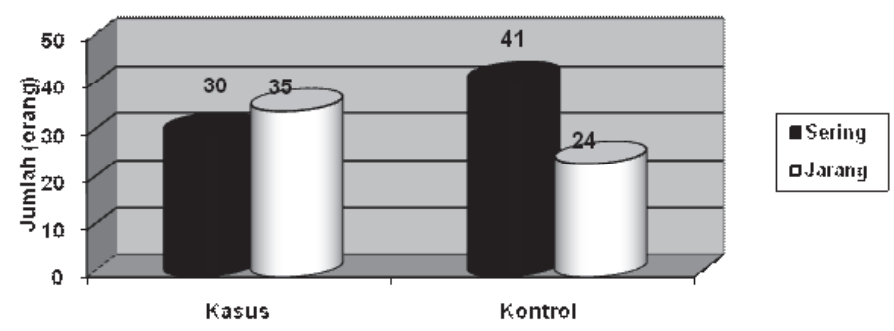

Gambar 5. Distribusi kasus dan kontrol berdasarkan frekuensi konsumsi sumber lemak tak jenuh

\section{Gambaran komponen sindroma metabolik}

Sindroma metabolik merupakan sekumpulan gejala yang mengarah pada timbulnya penyakit degeneratif. Seseorang dikatakan mengalami sindroma metabolik apabila ditemukan minimal 3 kriteria penilaian berikut seperti: kadar gula darah puasa lebih dari $110 \mathrm{mg} / \mathrm{dl}$, tekanan darah 130/85 mmHg, dan lingkar pinggang lebih dari $90 \mathrm{~cm}$ untuk laki-laki serta lebih dari $80 \mathrm{~cm}$ untuk perempuan atau kadar kolesterol HDL kurang dari $40 \mathrm{mg} / \mathrm{dl}$ pada laki-laki dan kurang dari $50 \mathrm{mg} / \mathrm{dl}$ pada perempuan.

Penilaian terhadap obesitas sentral dapat ditentukan berdasarkan lingkar pinggang (Waist Circumference). Hasil penelitian menunjukkan rata-rata lingkar pinggang kasus menurut jenis kelamin adalah $101,40 \mathrm{~cm}( \pm 7,92)$ pada laki-laki dan $92,37 \mathrm{~cm}( \pm 6,87)$ pada perempuan, sedangkan kontrol adalah $83,97 \mathrm{~cm}( \pm 8,15)$ pada laki-laki dan $81,30 \mathrm{~cm}( \pm 8,33)$ pada perempuan. Kadar gula darah yang dianggap normal adalah berkisar antara 70-110 $\mathrm{mg} / \mathrm{dl}$. Rata-rata kadar gula darah puasa kasus $132 \mathrm{mg} /$ dl $( \pm 32 \mathrm{mg} / \mathrm{dl})$, sedangkan kadar gula darah pada kontrol $95 \mathrm{mg} / \mathrm{dl}( \pm 9,8 \mathrm{mg} / \mathrm{dl})$. Rata-rata tekanan diastolik pada kasus adalah $93,3 \mathrm{mmHg}( \pm 8,5 \mathrm{mmHg})$ dan kontrol 78,0 $\mathrm{mmHg}( \pm 7,7 \mathrm{mmHg})$. Sedangkan rata-rata tekanan darah sistolik pada kasus adalah $141,4 \mathrm{mmHg}( \pm 12,9 \mathrm{mmHg})$ dan pada kontrol $118,8 \mathrm{mmHg}( \pm 9,3 \mathrm{mmHg})$. Ditemukan $13,3 \%$ kontrol yang memiliki tekanan darah di atas normal $(>130 / 85 \mathrm{mmHg})$. Nilai rerata komponen sindroma metabolik pada kasus dan kontrol disajikan pada Tabel 2.

Tabel 2. Nilai rerata komponen sindroma metabolik pada kasus dan kontrol

\begin{tabular}{|c|c|c|c|}
\hline $\begin{array}{l}\text { Komponen } \\
\text { sindroma } \\
\text { metabolik }\end{array}$ & $\begin{array}{c}\text { Subjek } \\
\text { penelitian }\end{array}$ & Rerata & $\begin{array}{c}\mathbf{p} \\
\text { value }\end{array}$ \\
\hline \multirow[t]{2}{*}{ Lingkar pinggang } & Kasus & $97,23 \mathrm{~cm}( \pm 8,6)$ & 0,01 \\
\hline & Kontrol & $83,93 \mathrm{~cm}( \pm 7,6)$ & \\
\hline \multirow{2}{*}{$\begin{array}{l}\text { Kadar gula darah } \\
\text { puasa }\end{array}$} & Kasus & $132 \mathrm{mg} / \mathrm{dl}( \pm 32,7)$ & 0,01 \\
\hline & Kontrol & $95 \mathrm{mg} / \mathrm{dl}( \pm 9,8)$ & \\
\hline \multicolumn{4}{|c|}{ Tekanan darah } \\
\hline \multirow[t]{2}{*}{ Diastolik } & Kasus & $93,3 \mathrm{mmHg}( \pm 8,5)$ & 0,01 \\
\hline & Kontrol & $78,0 \mathrm{mmHg}( \pm 7,7)$ & \\
\hline \multirow[t]{2}{*}{ Sistolik } & Kasus & $141,4 \mathrm{mmHg}( \pm 12,9)$ & 0,01 \\
\hline & Kontrol & $118,8 \mathrm{mmHg}( \pm 9,3)$ & \\
\hline
\end{tabular}

Kejadian sindroma metabolik berdasarkan persentase konsumsi lemak

Pola konsumsi lemak meliputi persentase energi lemak yaitu lemak total, persentase penggunaan lemak jenuh, kolesterol, dan lemak tak jenuh dibandingkan dengan total energi yang dikonsumsi dalam sehari serta frekuensi konsumsi jenis sumber lemak. Hasil penelitian menunjukkan bahwa terdapat perbedaan yang signifikan antara konsumsi lemak total, kolesterol, dan konsumsi lemak jenuh dengan kejadian sindroma metabolik pada kasus dan kontrol. Persentase konsumsi lemak yang melebihi anjuran persentase lemak yang dianjurkan dalam sehari memiliki risiko 2,5 kali lebih besar 
Tabel 3. Kejadian sindroma metabolik berdasarkan persentase konsumsi lemak

\begin{tabular}{|c|c|c|c|c|c|c|c|}
\hline \multirow{2}{*}{ Persentase konsumsi lemak } & \multicolumn{2}{|c|}{ Kasus } & \multicolumn{2}{|c|}{ Kontrol } & \multirow{2}{*}{ OR } & \multirow{2}{*}{$95 \% \mathrm{Cl}$} & \multirow{2}{*}{$\begin{array}{c}p \\
\text { value }\end{array}$} \\
\hline & $\mathbf{n}$ & $\%$ & $\mathbf{n}$ & $\%$ & & & \\
\hline \multicolumn{8}{|l|}{ Lemak total } \\
\hline Tidak baik $(>25 \%)$ & 53 & 81,5 & 41 & 63,1 & 2,58 & $1,2-5,78$ & 0,021 \\
\hline Baik $(\leq 25 \%)$ & 12 & 18,5 & 24 & 36,9 & & & \\
\hline Total & 65 & 100,0 & 65 & 100,0 & & & \\
\hline \multicolumn{8}{|l|}{ Lemak jenuh } \\
\hline Tidak baik $(>10 \%)$ & 59 & 90,8 & 49 & 75,4 & 3,21 & $1,17-8,83$ & 0,024 \\
\hline Baik $(\leq 10 \%)$ & 6 & 9,2 & 16 & 24,6 & & & \\
\hline Total & 65 & 100,0 & 65 & 100,0 & & & \\
\hline \multicolumn{8}{|l|}{ Lemak tak jenuh } \\
\hline $\begin{array}{l}\text { Tidak baik } \\
(<3 \% \text { dan }>7 \%)\end{array}$ & 4 & 6,2 & 9 & 13,8 & 0,48 & $0,12-1,39$ & 0,154 \\
\hline Baik (3-7\%) & 61 & 93,8 & 56 & 86,2 & & & \\
\hline Total & 65 & 100,0 & 65 & 100,0 & & & \\
\hline \multicolumn{8}{|l|}{ Kolesterol } \\
\hline Tidak baik $(>300 \mathrm{mg})$ & 36 & 55,4 & 20 & 30,8 & 2,79 & $1,36-5,73$ & 0,005 \\
\hline Baik $(\leq 300 \mathrm{mg})$ & 29 & 44,6 & 45 & 69,2 & & & \\
\hline Total & 65 & 100,0 & 65 & 100,0 & & & \\
\hline
\end{tabular}

mengalami kejadian sindroma metabolik dibandingkan dengan persentase lemak yang baik $(p<0,05)$. Konsumsi lemak jenuh lebih dari $10 \%$ total energi meningkatkan risiko kejadian sindroma metabolik 3,2 kali lebih besar dibandingkan konsumsi kurang atau sama dengan $10 \%$. Kejadian sindroma metabolik berdasarkan persentase konsumsi lemak disajikan pada Tabel 3.

Tabel 3 juga memperlihatkan bahwa kolesterol merupakan faktor risiko terhadap kejadian sindroma metabolik. Subjek dengan konsumsi lebih dari 300 mg per hari berisiko 2,79 kali lebih besar dibandingkan dengan konsumsi kurang atau sama dengan $300 \mathrm{mg}$ per hari. Sebaliknya terlihat bahwa konsumsi lemak tak jenuh bukan merupakan faktor risiko terhadap kejadian sindroma metabolik $(\mathrm{OR}=0,48 ; 95 \% \mathrm{Cl}=0,12-1,39)$.

\section{Kejadian sindroma metabolik berdasarkan frekuensi sumber lemak}

Bahan makanan sumber lemak yang biasa dikonsumsi oleh subjek yang bersumber dari protein nabati yaitu kacang-kacangan, minyak kelapa, margarin, dan sumber hewani seperti daging dan olahannya. Makanan tersebut merupakan sumber asam lemak jenuh, kolesterol, dan sumber asam lemak tak jenuh. Hasil penelitian menunjukkan bahwa terdapat perbedaan yang signifikan antara frekuensi konsumsi sumber lemak jenuh dengan kejadian sindroma metabolik. Subjek yang mengonsumsi sumber lemak jenuh dan kolesterol dengan frekuensi lebih sering ( $>1 x$ seminggu) berisiko 3,6 kali lebih besar mengalami kejadian sindroma metabolik dibandingkan dengan subjek yang mengonsumsi sumber lemak jenuh jarang ( $\leq 1 \mathrm{x}$ seminggu) $(\mathrm{OR}=3,64$; $95 \% \mathrm{Cl}=1,5-8,65)$ (Tabel 4).

Tabel 4 juga memperlihatkan bahwa tidak terdapat perbedaan yang signifikan antara frekuensi konsumsi sumber lemak tak jenuh dengan kejadian sindroma metabolik. Frekuensi konsumsi sumber lemak tak jenuh bukan merupakan faktor risiko terhadap kejadian sindroma metabolik $(p<0,05)$.

\section{Sindroma metabolik dan pola konsumsi lemak}

Sindroma metabolik merupakan sekumpulan gejala yang ditemukan pada seseorang yang mengarah

Tabel 4. Kejadian sindroma metabolik berdasarkan frekuensi konsumsi sumber lemak

\begin{tabular}{|c|c|c|c|c|c|c|c|}
\hline \multirow{2}{*}{$\begin{array}{l}\text { Frekuensi sumber } \\
\text { lemak }\end{array}$} & \multicolumn{2}{|c|}{ Kasus } & \multicolumn{2}{|c|}{ Kontrol } & \multirow{2}{*}{ OR } & \multirow{2}{*}{$95 \% \mathrm{Cl}$} & \multirow{2}{*}{ p valuei } \\
\hline & $\mathbf{n}$ & $\%$ & $\mathbf{n}$ & $\%$ & & & \\
\hline \multicolumn{8}{|l|}{ Lemak jenuh } \\
\hline Sering $(>1 \mathrm{x} / \mathrm{mg})$ & 56 & 86,2 & 41 & 63,1 & 3,64 & $1,55-8,65$ & 0,003 \\
\hline Jarang $(\leq 1 \mathrm{x} / \mathrm{mg})$ & 9 & 13,8 & 24 & 36,9 & & & \\
\hline Total & 65 & 100,0 & 65 & 100,0 & & & \\
\hline \multicolumn{8}{|l|}{ Lemak tak jenuh } \\
\hline Sering $(<1 \mathrm{x} / \mathrm{mg})$ & 30 & 46,2 & 24 & 36,9 & 1,46 & $0,72-2,95$ & 0,28 \\
\hline Jarang $(<1 \mathrm{x} / \mathrm{mg})$ & 35 & 53,8 & 41 & 63,1 & & & \\
\hline Total & 65 & 100,0 & 65 & 100,0 & & & \\
\hline
\end{tabular}


kepada timbulnya penyakit degeneratif seperti diabetes mellitus, arterosklerosis, dan penyakit jantung koroner. Permasalahan sindroma metabolik terus berkembang yang erat kaitannya dengan perubahan gaya hidup di masyarakat.

Hasil penelitian terhadap komponen sindroma metabolik menunjukkan bahwa rata-rata lingkar pinggang pada kasus melebihi normal dengan rata-rata $101,40 \mathrm{~cm}$ $( \pm 7,92)$ pada laki-laki dan $92,37 \mathrm{~cm}( \pm 6,87)$ pada perempuan dan terdapat perbedaan yang signifikan dengan lingkar pinggang pada kontrol $(p<0,05)$ (Tabel 2). Lingkar pinggang di atas normal menunjukkan adanya penimbunan jaringan lemak abdominal atau obesitas sentral. Obesitas jenis ini dianggap lebih kuat hubungannnya dengan sindroma metabolik dibandingkan lemak subkutan atau lemak tubuh total. Lemak di daerah visceral lebih bersifat lipolitik dan merupakan penyebab resistensi insulin dan hiperinsulinemia akibat meningkatnya produksi oleh sel beta pankreas dan berkurangnya pengeluaran insulin di hati (12).

Peningkatan kadar gula darah pada kasus dan intoleransi glukosa merupakan salah satu manifestasi sindroma metabolik yang menjadi awal penyakit diabetes mellitus. Terdapat hubungan yang kuat antara intoleransi glukosa dan risiko kardiovaskuler pada sindroma metabolik dan diabetes yang dipicu oleh obesitas, perubahan gaya hidup, pola makan yang salah, dan aktivitas fisik kurang (13).

Terdapat perbedaan yang signifikan antara tekanan darah pada kasus dan kontrol $(p<0,05)$ (Tabel 2). Peningkatan tekanan darah atau hipertensi pada subjek merupakan faktor risiko penyakit kardiovaskuler dan terdapat hubungan yang signifikan antara hipertensi, resistensi insulin, dan penyakit kardiovaskuler. Publikasi hasil penelitian di berbagai negara di Eropa menunjukkan bahwa sekitar $50 \%$ pasien yang memiliki hipertensi essensial juga mengalami resistensi insulin serta memiliki komponen sindroma metabolik lainnya seperti kadar trigliserida yang tinggi dan HDL kolesterol yang rendah (14).

Lemak memiliki peranan yang penting bagi tubuh. Selain sebagai sumber energi, lemak diperlukan oleh tubuh sebagai pelarut vitamin larut lemak, komponen membran sel sebagai hormon, sistem imun, dan termoregulator. Asupan lemak dalam jumlah yang memadai serta berimbang antara lemak jenuh, tak jenuh, kolesterol, dan lainnya akan mampu memenuhi fungsi di atas. Anjuran asupan lemak diharapkan tidak melebihi 25\% dari total energi yang dikonsumsi sehari, lemak jenuh maksimal 10\% total energi, dan lemak tak jenuh berkisar 3-7\% total energi.

Hasil penelitian menunjukkan bahwa sebagian besar kasus (81,5\%) memiliki persentase konsumsi lemak tinggi (>25\%), demikian juga proporsi konsumsi lemak jenuh dan kolesterol lebih dari $300 \mathrm{mg} / \mathrm{dl}$ lebih banyak ditemukan pada kasus $(p<0,05)$. Kondisi ini juga diikuti dengan peningkatan frekuensi penggunaan sumber lemak jenuh dan kolesterol. Proporsi kasus yang mengonsumsi lemak jenuh dengan frekuensi sering ( $>1 \mathrm{x}$ seminggu) lebih banyak yaitu $90,8 \%$ dan konsumsi kolesterol lebih dari 300 mg sebanyak $55,4 \%$.

Penelitian yang hampir sama dilakukan pada penduduk di Amerika Utara juga menunjukkan bahwa persentase konsumsi lemak dalam bentuk lemak jenuh sekitar $60 \%$ dari lemak total (15). Tingginya asupan dan kadar asam lemak jenuh berimplikasi terhadap peningkatan LDL kolesterol darah, selanjutnya menumpuk pada dinding pembuluh darah yang menimbulkan penyempitan pembuluh darah sehingga lemak jenuh berisiko tinggi terhadap arterosklerosis dan penyakit kardiovaskuler. Pada umumnya sumber utama lemak jenuh bersumber dari hewani yaitu berbagai jenis daging dan hasil olahannnya, dari nabati banyak terdapat pada minyak kelapa dan minyak yang mengalami hidrogenasi atau lemak trans seperti pada mentega (16).

Kolesterol mempunyai peranan penting bagi tubuh, tetapi apabila dikonsumsi berlebihan akan membahayakan karena menumpuk pada pembuluh darah dan menyebabkan arterosklerosis serta sumbatan pada pembuluh darah. Tingginya asupan kolesterol pada subjek disebabkan karena sebagian besar subjek mengonsumsi sumber hewani seperti daging ayam, daging babi serta hasil olahannya. Makanan dengan kandungan kolesterol yang tinggi menyebabkan peningkatan kadar kolesterol darah, kolesterol LDL, dan risiko penyakit kardiovaskuler, sebaliknya mengonsumsi makanan dengan kandungan koleterol kurang dari 200 mg memiliki profil lipid yang lebih baik yang ditunjukkan oleh kadar HDL, LDL, dan trigliserida yang normal (15).

\section{Analisis faktor risiko pola konsumsi lemak terhadap kejadian sindroma metabolik}

Hasil penelitian menunjukkan konsumsi lemak yang tidak baik melebihi anjuran persentase lemak yang dianjurkan dalam sehari memiliki risiko 2,58 kali lebih besar terhadap kejadian sindroma metabolik, dibandingkan dengan konsumsi lemak yang baik (OR 2,58; 95\% Cl=1,2-5,8) (Tabel 3). Apabila dikaitkan dengan frekuensi penggunaan sumber lemak, hasil penelitian juga menunjukkan bahwa terdapat perbedaan yang signifikan antara frekuensi konsumsi sumber lemak jenuh dengan kejadian sindroma metabolik $(\mathrm{OR}=3,64 ; 95 \% \mathrm{Cl}=1,5-8,65)$ (Tabel 4). Sebaliknya konsumsi lemak tak jenuh bukan merupakan faktor risiko terhadap kejadian sindroma metabolik (OR = 0,48; 95\% Cl= 0,12-1,39) (Tabel 3), demikian juga tak terdapat hubungan signifikan antara frekuensi konsumsi sumber lemak tak jenuh dengan kejadian sindroma metabolik $(\mathrm{OR}=1,46$; 95\% $\mathrm{Cl}=0,72-2,95)$ (Tabel 4).

Hasil penelitian ini sejalan dengan hasil di Teheran yang menemukan bahwa ada hubungan yang signifikan 
antara pola konsumsi dengan kejadian sindroma metabolik pada penduduk wanita dewasa (3). Mereka yang memiliki pola konsumsi Western memiliki risiko tinggi terhadap peningkatan komponen sindroma metabolik seperti resistensi insulin, peningkatan LDL kolesterol, dan tekanan darah. Penelitian di Jepang menunjukkan bahwa tingginya persentase energi yang bersumber dari lemak berhubungan dengan risiko penyakit DM pada daerah industri di Jepang yang ditunjukkan oleh IMT, obesitas sentral, glukosuria, dan resistensi insulin lebih tinggi dibandingkan negara nonindustri (16).

Pola konsumsi dengan komposisi lemak tinggi seperti yang terjadi pada subjek merupakan salah satu ciri gaya hidup masyarakat modern. Diet model tersebut umumnya mengarah pada obesitas dan selanjutnya dapat berkembang menjadi sindroma metabolik (17). Pola makan western umumnya mengandung kalori dan lemak tinggi terutama kandungan lemak jenuh dan kolesterol. Tingginya persentase asupan lemak, baik lemak total maupun lemak jenuh dari total kalori menyebabkan penimbunan lemak di jaringan adiposa terutama di daerah visceral dan peningkatan kadar lemak dalam darah seperti peningkatkan kadar trigliserida, koleterol total, dan kolesterol LDL. Penimbunan lemak dalam bentuk trigliserida di daerah sentral akan menyebabkan peningkatan kadar asam lemak bebas dan peningkatan oksidasi lipid yang meningkatkan metabolisme asetil ko-A. Akibatnya terjadi hambatan kerja insulin dan mobilisasi glukosa ke dalam sel sehingga timbul hiperglikemia. Peningkatan kadar trigliserida di dalam tubuh menyebabkan peningkatan kadar kolesterol total dan LDL kolesterol, penimbunan lemak di arteri yang disebut "Plaque" yang menyebabkan darah yang mengandung oksigen sulit mencapai jantung karena terjadi penyempitan pembuluh darah yang pada akhirnya meningkatkan kejadian serangan jantung dan stroke (18). Mekanisme pola makan khususnya pola makan tinggi lemak dengan kandungan asam lemak tertentu terhadap berkembangnya sindroma metabolik sebenarnya belum diketahui pasti (17). Diperkirakan bahwa proporsi konsumsi asam lemak jenuh yang lebih tinggi meningkatkan kadar asam lemak jenuh dalam serum, kadar insulin plasma serta penurunan sensitivitas insulin.

Konsumsi asam lemak tak jenuh ganda justru dapat menurunkan risiko sindroma metabolik dengan meningkatkan kadar kolesterol HDL dan menurunkan kadar kolesterol total atau timbunan kolesterol dalam pembuluh darah sehingga mencegah terjadinya arterosklerosis dan penyakit jantung koroner. Di samping itu asam lemak tak jenuh ganda meningkatkan elastisitas pembuluh darah sehingga mengurangi risiko hipertensi. Penelitian di Teheran menunjukkan bahwa masyarakat yang mengkonsumsi diet sehat seperti sayuran, kacangkacangan, dan buah-buahan memiliki risiko yang rendah terhadap sindroma metabolik (3).

\section{KESIMPULAN DAN SARAN}

Pola konsumsi lemak masyarakat perkotaan di Denpasar menunjukkan perbedaan signifikan pada kelompok yang mengalami sindroma metabolik dan yang tidak. Kelompok yang mengalami sindroma metabolik mengonsumsi lemak total, lemak jenuh, dan kolesterol dengan proporsi lebih banyak. Nilai rerata komponen sindroma metabolik pada kelompok yang mengalami sindroma metabolik yaitu lingkar pinggang $101,40 \mathrm{~cm}$ pada laki-laki dan $92,37 \mathrm{~cm}$ pada perempuan, kadar gula darah $132 \mathrm{mg} / \mathrm{dl}$, dan tekanan darah sistolik $141,4 \mathrm{mmHg} /$ diastolik 93,3 $\mathrm{mmHg}$. Persentase konsumsi lemak total, lemak jenuh, kolesterol yang kurang baik, dan frekuensi sumber lemak sering merupakan faktor risiko kejadian sindroma metabolik pada masyarakat perkotaan di Denpasar, sedangkan konsumsi lemak tak jenuh serta frekuensi sumber lemak tak jenuh bukan merupakan faktor risiko kejadian sindroma metabolik.

Disarankan agar masyarakat perkotaan di Denpasar menerapkan pola menu seimbang dengan mengurangi konsumsi makanan yang mengandung lemak jenuh dan kolesterol tinggi, serta meningkatkan konsumsi makanan yang mengandung lemak tak jenuh seperti pada ikan, minyak ikan, minyak sayur, dan kacang. Diperlukan adanya pemberian penyuluhan yang lebih intensif kepada masyarakat tentang pentingnya pola hidup dan makanan yang sehat sesuai prinsip gizi seimbang untuk mempertahankan kesehatan dan mencegah terhadap timbulnya masalah kesehatan seperti sindroma metabolik.

\section{RUJUKAN}

1. Nursanyoto H, Yuni G, Suiraoka. Dampak pergeseran pola konsumsi terhadap derajat kesehatan dalam konteks dinamika variabel demografi masyarakat perkotaan di Denpasar. Jakarta: Depkes RI; 1999.

2. Satoto. Kegemukan, obesitas dan penyakit degeneratif: epidemiologi dan strategi penanggulangan dalam FG Winarno. Prosiding Widya Karya Pangan Dan Gizi VI. Jakarta: LIPI; 1998.

3. Esmaillzadeh A, Mosug KFB, Willet W. Dietary pattern, insulin resistance and prevalence of the metabolic syndrome in women. Am J Clin Nutr 2007; 85: $910-8$.

4. Mayo Clinic. Metabolic syndrome [serial online] 2007 [cited 2009 Feb 20]. Avalaible from: http//www. mayoclinic.com.

5. Badan Penelitian dan Pengembangan Kesehatan Depkes RI. Laporan hasil riset kesehatan dasar (Riskesdas) [serial online] 2007 [cited 2010 Des 2]. Available from http://www. dostoc.com/18707850. Laporan Hasil Riset Kesehatan Dasar 2007. 
6. Gotera W. Studi epidemiologis obesitas sentral dan sindrome metabolik pada penduduk desa dan kota di Bali. Majalah Penyakit Dalam 2003; 4(3).

7. Waspadji S. Diabetes mellitus: mekanisme dasar dan pengelolaan yang rasional. dalam: penatalaksanaan diabetes mellitus terpadu cet 3. Jakarta: Pusat Diabetes dan Lipid RSUP Nasional Cipto Mangunkusuma dan FKUI; 2007.

8. Klein S, Sheard NF, Sunyer XP, Daly A, Rosett JW, Kulkarni K, Clark NG. Weight management trought life style modification for prevention and management type 2 diabetes. Am J Nutr 2004; 80:257-63.

9. Dewi IGASK, Pramantara IDP, Pangastuti R. Pola makan berhubungan dengan sindrom metabolik pada lanjut usia di Poliklinik Geriatri RSUP Sanglah Denpasar. Jurnal Gizi Klinik Indonesia 2010; 6(3):105-13.

10. Sudarminingsih S, Lestariana W, Susetyowati. Hubungan pola makan dengan sindroma metabolik pada karyawan PT.Unocal Oil Company di offshore Balikpapan Propinsi Kalimantan Timur. Jurnal Gizi Klinik Indonesia 2007; 4(2):63-8.

11. Sastroasmoro, S. Dasar-dasar metodologi penelitian klinis edisi II. Jakarta: Sugeng Seto; 2002.
12. Arifin A. Obesitas visceral dan sindroma metabolik. Prosiding Pertemuan IImiah Nasional Dietetik II. Bandung: ASDI; 2005.

13. Soegondo S, Gustaviani R. Sindroma metabolik buku ajar ilmu penyakit dalam II. Jakarta: FK UI; 2006.

14. Reaven, Gerad M. The metabolic syndrome: is this diagnosis necessary. J Am Clin Nutr 2006; 83:123747.

15. Rolfes SR, Kathryn P, Ellie W. Understanting normal and clinical nutrition. New York: Thomson Wadsworth; 2004.

16. Tomisaka K, Lako J, Maruyama C, Anh NTL, Lien DTK, Khoi H, Chuyen VN. Dietary pattern and risk factor for type 2 diabetes mellitus in Fijian, Japanese, Vietnamese populations. Asia Pacific J Clin Nutr 2002; 11(1):8-12.

17. WHO. Facts related to chronic disease: non communicable disease prevention and health promotion [serial online] 2003 [cited 2005 Apr 14]. Avalaible from: http://www.who.int.

18. Mathur R. Metabolic sindrome [serial online] 2009 [cited 2009 Feb 20]. Avalaible from: http/www.medecin .com. 